\title{
Fe(III) Complexes Based on Mono- and Bis-pyrazolyl- s-triazine Ligands: Synthesis, Molecular Structure, Hirshfeld, and Antimicrobial Evaluations
}

\author{
Saied M. Soliman ${ }^{1, *(0)}$, Hessa H. Al-Rasheed ${ }^{2}$, Jörg H. Albering ${ }^{3}$ and Ayman El-Faham ${ }^{1,2, *(1)}$ \\ 1 Department of Chemistry, Faculty of Science, Alexandria University, P.O. Box 426, Ibrahimia, \\ Alexandria 21321, Egypt \\ 2 Department of Chemistry, College of Science, King Saud University, P.O. Box 2455, \\ Riyadh 11451, Saudi Arabia; halbahli@ksu.edu.sa \\ 3 Graz University of Technology, Mandellstr. 11/III, A-8010 Graz, Austria; joerg.albering@tugraz.at \\ * Correspondence: saied1soliman@yahoo.com (S.M.S.); aelfaham@ksu.edu.sa (A.E.-F.)
}

Academic Editors: Vera L. M. Silva and Artur M. S. Silva

Received: 15 November 2020; Accepted: 3 December 2020; Published: 5 December 2020

\begin{abstract}
The self-assembly of iron(III) chloride with three pyrazolyl-s-triazine ligands, namely 2,4bis(3,5-dimethyl-1H-pyrazol-1-yl)-6-(piperidin-1-yl)-1,3,5-triazine ( $\left.{ }^{P i p} \mathbf{B P T}\right), 4$-(4,6-bis(3,5-dimethyl-1Hpyrazol-1-yl)-1,3,5-triazin-2-yl)morpholine (Morph $\mathbf{B P T})$, and 4,4'-(6-(3,5-dimethyl-1H-pyrazol-1-yl)-1,3,5triazine-2,4-diyl)dimorpholine ( $\left.{ }^{\text {bisMorph }} \mathbf{P T}\right)$ afforded [Fe( $\left.\left.{ }^{\mathrm{Pip} B P T}\right) \mathrm{Cl}_{2}\right]\left[\mathrm{FeCl}_{4}\right](\mathbf{1}),\left[\mathrm{Fe}\left({ }^{\mathrm{Morph}} \mathrm{BPT}\right) \mathrm{Cl}_{2}\right]\left[\mathrm{FeCl}_{4}\right]$ (2), and [H( $\left.\left.{ }^{\text {bisMorph }} \mathrm{PT}\right)\right]\left[\mathrm{FeCl}_{4}\right]$. bisMorph $\mathrm{PT} .2 \mathrm{H}_{2} \mathrm{O}(\mathbf{3})$, respectively, in good yield. In complexes $\mathbf{1}$ and 2, the $\mathrm{Fe}(\mathrm{III})$ is pentacoordinated with three $\mathrm{Fe}-\mathrm{N}$ interactions from the pincer ligand and two coordinated chloride anions in the inner sphere, and $\mathrm{FeCl}_{4}{ }^{-}$in the outer sphere. Complex 3 is comprised of one protonated ligand as cationic part, one $\mathrm{FeCl}_{4}{ }^{-}$anion, and one neutral bisMorph $\mathbf{P T}$ molecule in addition to two crystallized water molecules. Analysis of molecular packing using Hirshfeld calculations indicated that $\mathrm{H} \ldots \mathrm{H}$ and $\mathrm{Cl} \ldots \mathrm{H}$ are the most important in the molecular packing. They comprised $40.1 \%$ and $37.4 \%$, respectively in $\mathbf{1}$ and $32.4 \%$ and $37.8 \%$, respectively in 2 . Complex $\mathbf{1}$ exhibited the most bioactivity against the tested microbes while 3 had the lowest bioactivity. The bisMorph PT and Morph $\mathbf{B P T}$ were inactive towards the tested microbes while Pip BPT was active. As a whole, the Fe(III) complexes have enhanced antibacterial and antifungal activities as compared to the free ligands.
\end{abstract}

Keywords: pyrazolyl-s-triazine; Fe(III); self-assembly; Hirshfeld; antimicrobial activity

\section{Introduction}

Iron is a readily available element, as it is considered to be one of the most abundant. It is cheap and has almost-negligible hazardous effects on the environment as it has low toxicity [1-3]. Iron compounds play a crucial role in ammonia production by the Haber-Bosch process. On other hand, iron and its compounds have a key role in homogenous molecular catalysis [4-7].

Bis-pyrazolyl-s-triazine (BPT) ligands are a class of chelators which have been utilized in the synthesis of several divalent metal ion complexes with interesting molecular and supramolecular structures [8-13]. These s-triazine pincer-type complexes can be easily synthesized using self-assembly in a water-alcohol mixture. Additionally, they have extra-stability due to the chelate effect. Although iron has low toxicity, there are many problems due to high iron overload because it plays a major role in the generation of free radicals $[14,15]$. BPT ligands have key characteristics to act as a solution for this problem because they are powerful chelators.

On other hand, several organic-based antibacterial and antifungal drugs were discovered over the last few years [16]. Many of these antibiotics cannot overcome the problem of multidrug-resistant 
microbes [17-19]. Therefore, the replacement of these traditional antibiotics by other medications that can solve the problem of antibiotic-resistant pathogens has become an urgent need [17-19]. In this regard, some $\mathrm{Fe}(\mathrm{III})$ complexes have good antibacterial activity against a broad range of bacteria, but not fungi [20]. Others were found to have good antibacterial and moderate antifungal activities [20].

In the present work, we self-assembled three $\mathrm{Fe}(\mathrm{III})$ complexes by the direct reaction of $\mathrm{FeCl}_{3}$ with the mono- and bis-pyrazolyl-s-triazine ligands shown in Figure 1. Their structure aspects were studied using single-crystal X-ray diffraction in combination with Hirshfeld analysis. The antibacterial and antifungal activities of these Fe(III) complexes are also presented.<smiles>Cc1cc(C)n(-c2nc(N3CCCCC3)nc(-n3nc(C)cc3C)n2)n1</smiles>

${ }^{\text {Pip }}$ BPT<smiles>Cc1cc(C)n(-c2nc(N3CCOCC3)nc(-n3nc(C)cc3C)n2)n1</smiles>

${ }^{\text {Morph }}$ BPT<smiles>Cc1cc(C)n(-c2nc(N3CCOCC3)nc(N3CCOCC3)n2)n1</smiles>

bisMorph $^{\text {PT }}$

Figure 1. Structure of the mono- and bis-pyrazolyl-s-triazine ligands [21,22]. Ligands shown are: 2,4-bis(3,5-dimethyl-1H-pyrazol-1-yl)-6-(piperidin-1-yl)-1,3,5-triazine (Pip BPT), 4-(4,6-bis(3,5-dimethyl$1 H$-pyrazol-1-yl)-1,3,5-triazin-2-yl)morpholine (Morph BPT), and 4,4'-(6-(3,5-dimethyl-1H-pyrazol-1-yl)1,3,5-triazine-2,4-diyl)dimorpholine ( ${ }^{\text {bisMorph }} \mathbf{P T}$ ).

\section{Results and Discussion}

\subsection{Structure Description}

The crystals of the synthesized complexes were simply obtained from the direct reaction of the $\mathrm{Fe}(\mathrm{III})$ salt with the functional ligand in water-ethanol solvent mixture at room temperature using self-assembly. The X-ray single-crystal structure of the Fe(III) complexes are presented for the first time and the crystal data are listed in Table 1.

\subsubsection{Crystal Structure Description of $\left[\mathrm{Fe}\left({ }^{\mathrm{Pip}} \mathbf{B P T}\right) \mathrm{Cl}_{2}\right]\left[\mathrm{FeCl}_{4}\right](\mathbf{1})$}

Complex 1 crystallizes in the monoclinic crystal system with the space group $\mathrm{P} 21 / \mathrm{c}$ and $\mathrm{Z}=4$; the asymmetric unit comprises one $\left[\mathrm{Fe}\left({ }^{\mathrm{Pip}} \mathbf{B P T}\right) \mathrm{Cl}_{2}\right]\left[\mathrm{FeCl}_{4}\right]$ unit. The structure of the inner sphere complex in $\mathbf{1}$ consists of one cationic complex unit in which the Fe(III) ion is coordinated by Pip BPT in a tridentate pincer fashion and two chloride ions. The outer sphere is an anion: a tetrahedral $\mathrm{FeCl}_{4}{ }^{-} \mathrm{unit}$ (Figure 2). The Fe-N distances are significantly shorter for the Fe-N(s-triazine) than the Fe-N(pyrazole), where the two Fe-N(pyrazole) bonds are only slightly different (Table 2). The two Fe1-Cl1 and Fe1-Cl2 bonds have very close bond distances of 2.1699(6) $\AA$ and 2.1766(6) $\AA$, respectively. The coordination geometry of the five-coordinated Fe(III) ion is described using Addison criteria [23]. The coordination geometry, as shown in Figure 2, lies between the square pyramid and the trigonal bipyramid with a N3-Fe1-N2 angle $(\beta)$ of $146.46(6)^{\circ}$ and N1-Fe1-Cl2 angle $(\alpha)$ of $133.34(5)^{\circ}$, giving a $\tau=((\beta-\alpha) / 60)$ value of 0.22 . As a result, the coordination geometry around Fe(III) could be described as a distorted square pyramid. 
Table 1. Crystal data and structure refinement for the studied complexes.

\begin{tabular}{|c|c|c|c|}
\hline Compound & 1 & 2 & 3 \\
\hline Empirical formula & $\mathrm{C}_{18} \mathrm{H}_{24} \mathrm{Cl}_{6} \mathrm{Fe}_{2} \mathrm{~N}_{8}$ & $\mathrm{C}_{17} \mathrm{H}_{22} \mathrm{Cl}_{6} \mathrm{Fe}_{2} \mathrm{~N}_{8} \mathrm{O}$ & $\mathrm{C}_{32} \mathrm{H}_{51} \mathrm{Cl}_{4} \mathrm{FeN}_{14} \mathrm{O}_{6}$ \\
\hline Formula weight $(\mathrm{g} / \mathrm{mol})$ & 676.85 & 678.82 & 925.51 \\
\hline Temperature $(\mathrm{K})$ & $119(2)$ & $124(2)$ & $293(2)$ \\
\hline$\lambda(\AA)$ & 0.71073 & 0.71073 & 0.71073 \\
\hline Crystal system & Monoclinic & Orthorhombic & Triclinic \\
\hline Space group & $\mathrm{P} 2_{1} / \mathrm{c}$ & $\mathrm{Pbcm}$ & P-1 \\
\hline \multicolumn{4}{|l|}{ Unit cell dimensions } \\
\hline $\mathrm{a}(\AA)$ & $8.9549(3)$ & $8.5201(3)$ & 12.4352(15) \\
\hline $\mathrm{b}(\AA)$ & $15.7871(6)$ & 13.7094(5) & $12.8632(16)$ \\
\hline$c(\AA)$ & $19.9063(7)$ & $23.2383(9)$ & $15.6509(19)$ \\
\hline$\alpha\left(^{\circ}\right)$ & 90 & 90 & $76.955(3)$ \\
\hline$\beta\left(^{\circ}\right)$ & $99.457(2)$ & 90 & 89.531(3) \\
\hline$\gamma\left({ }^{\circ}\right)$ & 90 & 90 & $66.926(3)$ \\
\hline Volume $\left(\AA^{3}\right)$ & $2775.9(2)$ & $2714.4(2)$ & $2234.7(5)$ \\
\hline $\mathrm{Z}$ & 4 & 4 & 2 \\
\hline Density (calculated, $\mathrm{g} / \mathrm{cm}^{3}$ ) & 1.620 & 1.661 & 1.370 \\
\hline Absorption coefficient $\left(\mathrm{mm}^{-1}\right)$ & 1.647 & 1.687 & 0.633 \\
\hline$F(000)$ & 1368 & 1368 & 958 \\
\hline Crystal size $\left(\mathrm{mm}^{3}\right)$ & $0.29 \times 0.16 \times 0.09$ & $0.04 \times 0.12 \times 0.15$ & $0.26 \times 0.20 \times 0.08$ \\
\hline \multirow[t]{2}{*}{$\theta$ range $\left(^{\circ}\right)$} & 2.31 to 25.49 & 2.81 to 24.99 & 2.33 to 25.09 \\
\hline & $-10 \leq \mathrm{h} \leq 10$ & $-10 \leq \mathrm{h} \leq 10$ & $-14 \leq \mathrm{h} \leq 14$ \\
\hline Index ranges & $\begin{array}{c}-19 \leq \mathrm{k} \leq 19 \\
-24 \leq 1 \leq 24\end{array}$ & $\begin{array}{l}-16 \leq \mathrm{k} \leq 16 \\
-27 \leq 1 \leq 27\end{array}$ & $\begin{array}{l}-15 \leq \mathrm{k} \leq 15 \\
-18 \leq 1 \leq 18\end{array}$ \\
\hline Reflections collected & 38,064 & 21,560 & 64,462 \\
\hline Independent reflections & $5139[\mathrm{R}(\mathrm{int})=0.0427]$ & $2453[\mathrm{R}(\mathrm{int})=0.0294]$ & $7915[\mathrm{R}(\mathrm{int})=0.0769]$ \\
\hline Completeness to theta (\%) & 99.8 & 99.90 & 99.5 \\
\hline Refinement method & & Full-matrix least-squares on $\mathrm{F}^{2}$ & \\
\hline Data/restraints/parameters & $5139 / 0 / 311$ & $2453 / 0 / 207$ & $7909 / 0 / 528$ \\
\hline Goodness-of-fit on $\mathrm{F}^{2}$ & 1.045 & 1.083 & 1.008 \\
\hline Final $\mathrm{R}$ indices [I $>2 \operatorname{sigma}(\mathrm{I})]$ & $\mathrm{R} 1=0.0238, \mathrm{wR} 2=0.0530$ & $\mathrm{R} 1=0.0397, \mathrm{wR} 2=0.0988$ & $\mathrm{R}_{1}=0.0932, \mathrm{wR}_{2}=0.2007$ \\
\hline $\mathrm{R}$ indices (all data) & $\mathrm{R} 1=0.0334, \mathrm{wR} 2=0.0571$ & $\mathrm{R} 1=0.0440, \mathrm{wR} 2=0.1024$ & $\mathrm{R}_{1}=0.1654, \mathrm{wR}_{2}=0.2464$ \\
\hline Largest diff. peak and hole & 0.291 and -0.306 & 0.621 and -1.035 & 0.87 and -0.64 \\
\hline CCDC No. & 2044018 & 2044016 & 2044017 \\
\hline
\end{tabular}
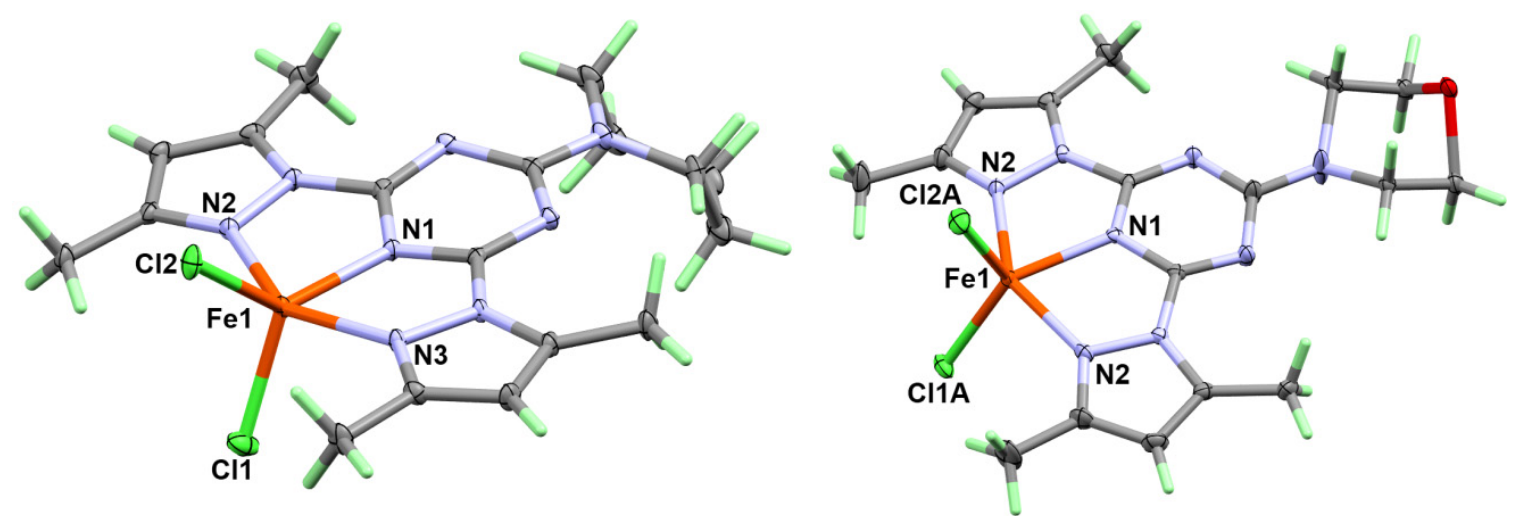

Figure 2. X-ray structure of complexes 1 (left) and 2 (right), the atoms have been drawn at a $30 \%$ probability level. The $\left[\mathrm{FeCl}_{4}\right]^{-}$anions in the outer sphere were omitted for better clarity.

The molecules of $\mathbf{1}$ are packed mainly by $\mathrm{Cl}$... H hydrogen bonds as shown in Figure 3 (upper part) and listed in Table 3. The donor-acceptor distances are 3.428(2) $\AA$, 3.622(2) $\AA$, and 3.723(2) $\AA$ for $\mathrm{C} 8-\mathrm{H} 8 \ldots \mathrm{Cl}$, C3-H3 .. C Cl3, and C5-H5B ... Cl6 hydrogen bonding interactions, respectively. The packing of complex molecules is shown in Figure 4 (upper part). The network connected via $\mathrm{Cl}$... $\mathrm{H}$ bridge interactions shows a 3D connectivity. 
Table 2. Bond distances and angles in $\mathbf{1}$.

\begin{tabular}{cccc}
\hline Atoms & Distance $(\AA)$ & Atoms & Distance (Å) \\
\hline Fe1-N1 & $2.0295(15)$ & Fe2-Cl3 & $2.1840(6)$ \\
Fe1-N3 & $2.0940(16)$ & Fe2-Cl4 & $2.1836(6)$ \\
Fe1-N2 & $2.1092(16)$ & Fe2-Cl5 & $2.1791(6)$ \\
Fe1-Cl1 & $2.1699(6)$ & Fe2-Cl6 & $2.1873(6)$ \\
Fe1-Cl2 & $2.1766(6)$ & & \\
\hline Atoms & Angle ( $\left.{ }^{\circ}\right)$ & Atoms & Angle ( $\left.{ }^{\circ}\right)$ \\
\hline N1-Fe1-N3 & $73.24(6)$ & N2-Fe1-Cl1 & $100.76(5)$ \\
N1-Fe1-N2 & $73.65(6)$ & N1-Fe1-Cl2 & $133.34(5)$ \\
N3-Fe1-N2 & $146.46(6)$ & N3-Fe1-Cl2 & $99.11(5)$ \\
N1-Fe1-Cl1 & $117.06(5)$ & N2-Fe1-Cl2 & $99.58(5)$ \\
N3-Fe1-Cl1 & $98.84(5)$ & Cl1-Fe1-Cl2 & $109.58(3)$ \\
\hline
\end{tabular}

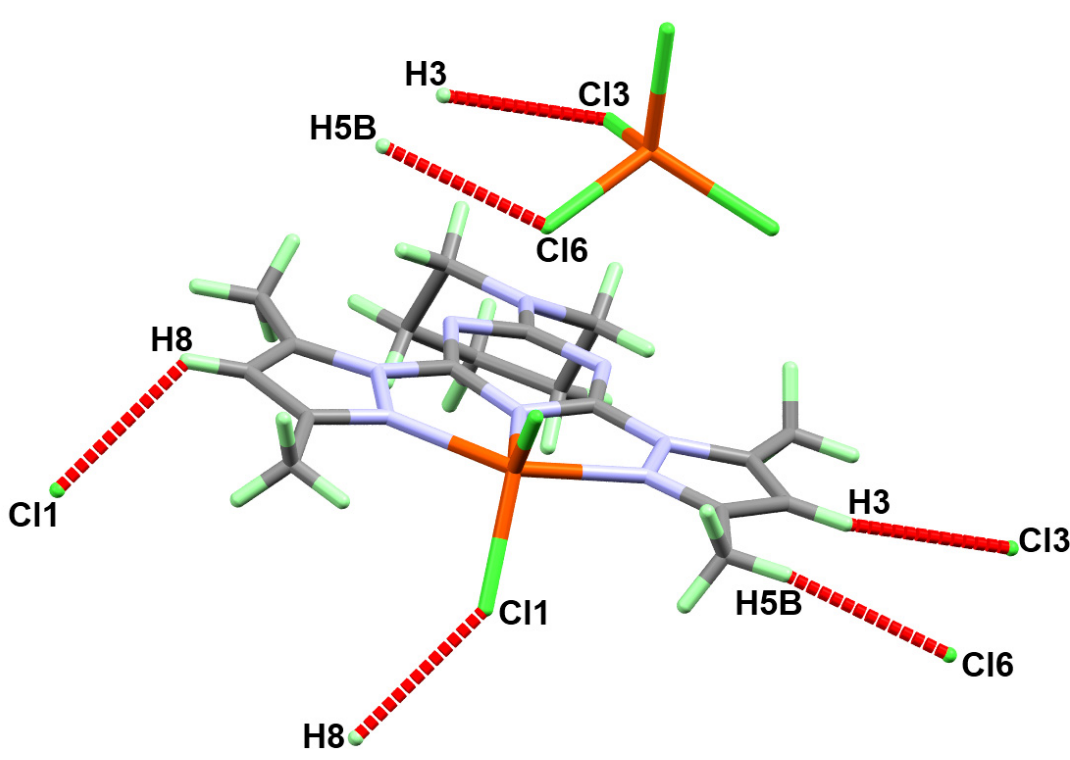

1

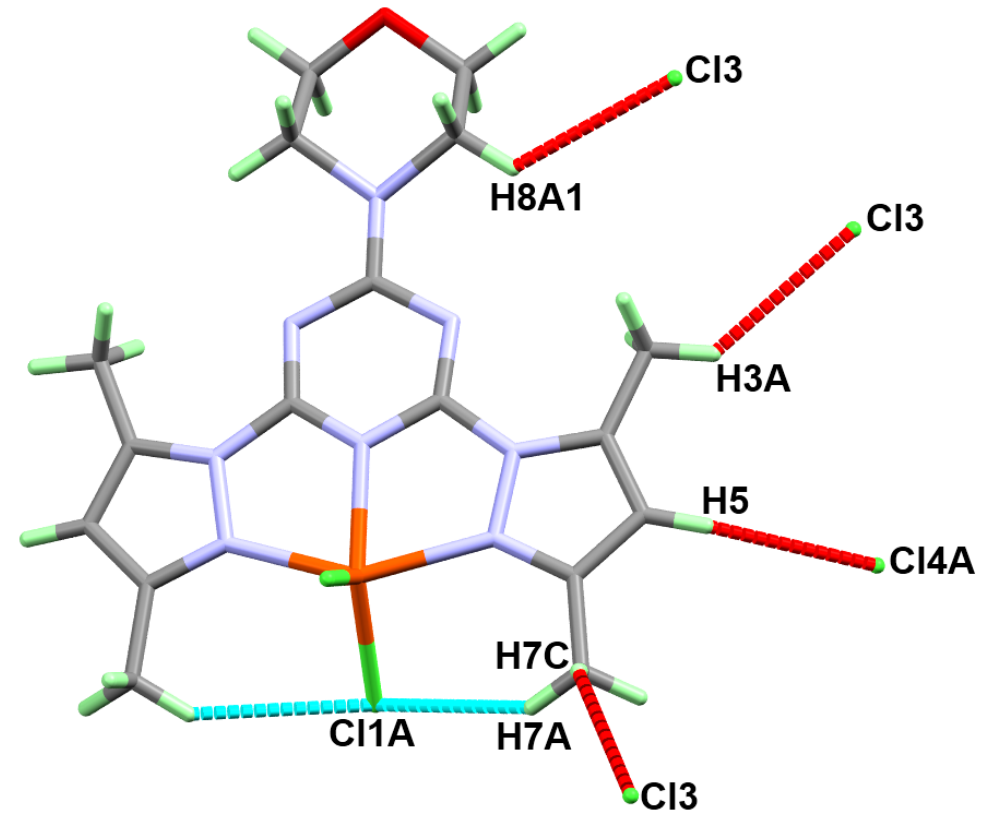

2

Figure 3. The hydrogen bond contacts in complexes $\mathbf{1}$ (upper) and $\mathbf{2}$ (lower). 
Table 3. Hydrogen bond parameters of complexes $\mathbf{1}$ and 2.

\begin{tabular}{|c|c|c|c|c|}
\hline Atoms & D-H (Å) & $\mathbf{H} \ldots \mathbf{A}(\AA)$ & D ... A ( $(\AA)$ & $\mathrm{D}-\mathrm{H} \ldots \mathrm{A}\left({ }^{\circ}\right)$ \\
\hline \multicolumn{5}{|c|}{ Complex 1} \\
\hline $\mathrm{C} 3-\mathrm{H} 3 \ldots \mathrm{Cl} 3^{\mathrm{i}}$ & 0.95 & 2.77 & $3.622(2)$ & 149 \\
\hline $\mathrm{C} 5-\mathrm{H} 5 \mathrm{~B} \ldots \mathrm{Cl}^{\mathrm{i}}$ & 0.98 & 2.8 & $3.723(2)$ & 158 \\
\hline $\mathrm{C} 8-\mathrm{H} 8 \ldots \mathrm{Cl}^{\mathrm{ii}}$ & 0.95 & 2.78 & $3.428(2)$ & 126 \\
\hline \multicolumn{5}{|c|}{${ }^{\mathrm{i}} 1+\mathrm{x}, \mathrm{y}, \mathrm{z}^{\mathrm{i}} 1+\mathrm{x}, \mathrm{y}, \mathrm{z}^{\mathrm{ii}} 1-\mathrm{x},-\mathrm{y}, 1-\mathrm{z}$ and } \\
\hline \multicolumn{5}{|c|}{ Complex 2} \\
\hline $\mathrm{C} 5-\mathrm{H} 5 \ldots \mathrm{Cl}_{4} \mathrm{~A}^{\mathrm{i}}$ & 0.95 & 2.79 & $3.651(5)$ & 152 \\
\hline C9A-H9A1 ... Cl1A ${ }^{\text {ii }}$ & 0.99 & 2.55 & $2.916(7)$ & 101 \\
\hline \multicolumn{5}{|c|}{${ }^{\mathrm{i}} \mathrm{x},-1+\mathrm{y}, \mathrm{z}$ and ${ }^{\text {ii }} 1-\mathrm{x}, 1 / 2+\mathrm{y}, 3 / 2-\mathrm{z}$} \\
\hline
\end{tabular}

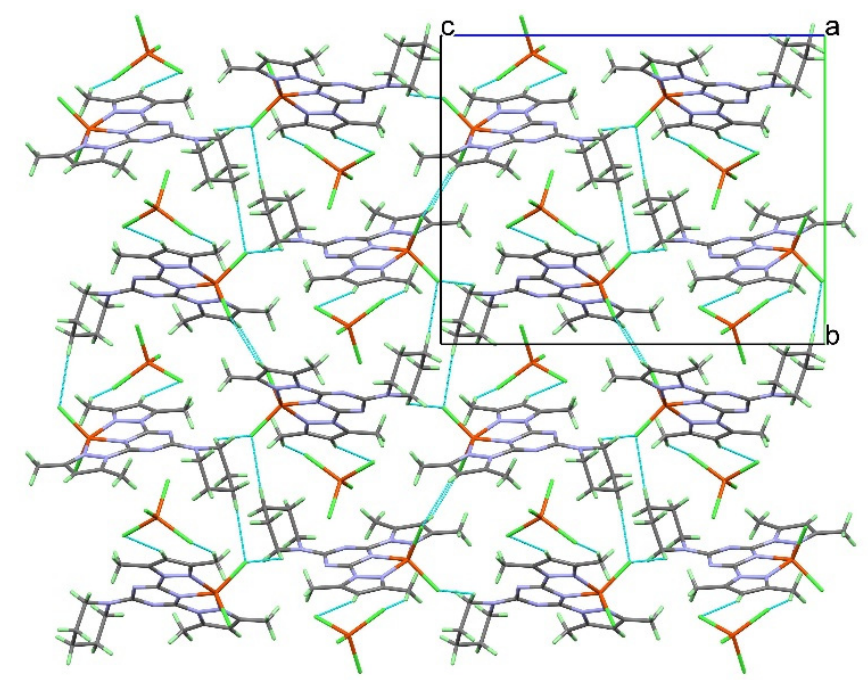

1
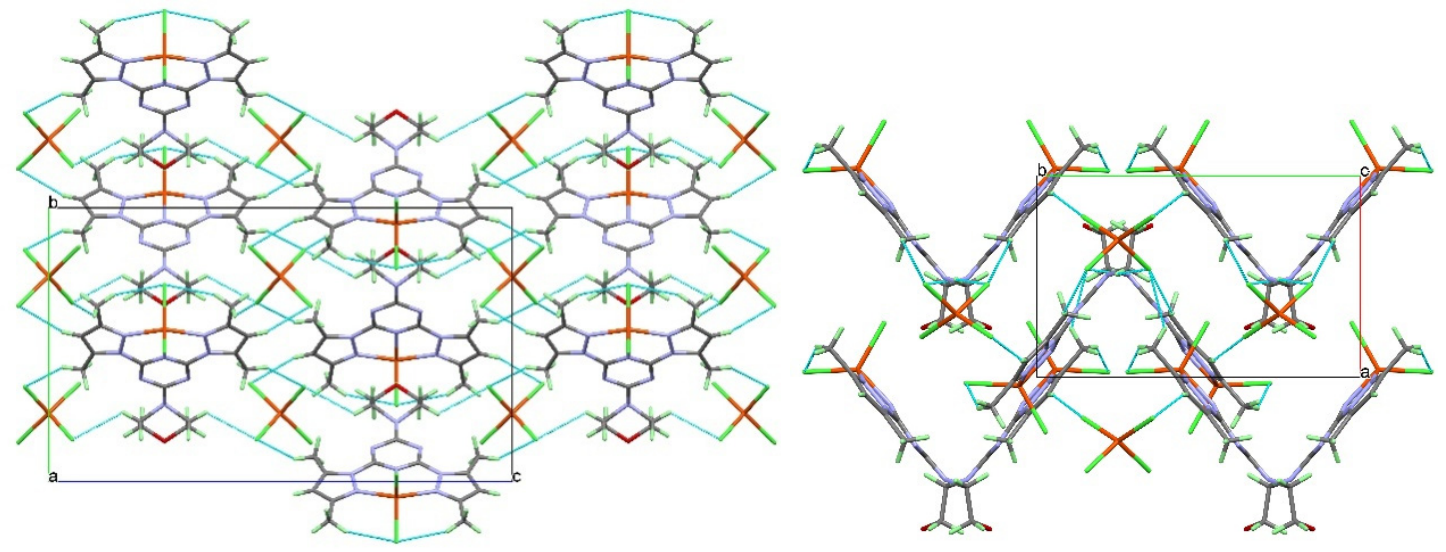

2

Figure 4. The hydrogen bond polymers in the crystal structures of complexes $\mathbf{1}$ (upper, view along the $a$-axis) and 2 (lower, views along the $a$ - and $c$-axes). The hydrogen bridges are shown as light-blue dotted lines.

2.1.2. Crystal Structure Description of $\left[\mathrm{Fe}\left({ }^{\mathrm{Morph}} \mathrm{BPT}\right) \mathrm{Cl}_{2}\right]\left[\mathrm{FeCl}_{4}\right]$ (2)

Complex $\mathbf{2}$ has a very close structure to $\mathbf{1}$, with one $\left[\mathrm{Fe}\left({ }^{\mathrm{Morph}} \mathbf{B P T}\right) \mathrm{Cl}_{2}\right]^{+}$as an inner sphere complex and $\left[\mathrm{FeCl}_{4}\right]^{-}$as a counter ion. The major difference is that complex $\mathbf{2}$ crystallizes in the more symmetric orthorhombic crystal system and space group $\mathrm{Pbcm}$ with half molecular formula as asymmetric unit. 
The molecule comprises a symmetrical plane passing vertically through the molecule, intersecting the $\mathrm{Fe}(\mathrm{III})$ center and the two chloride anions, and splitting the organic ligand into two halves. In this regard, there are two equidistant Fe-N(pyrazole) bonds with iron to nitrogen distance of 2.099(2) $\AA$ and one shorter Fe-N(s-triazine) bond (2.036(3) $\AA$ ). List of the most important bond distances are given in Table 4 . The coordination sphere is completed by the two coordinated chloride anions with iron to chlorine distances ranging from 2.090(6)-2.262(5) $\AA$ for the two disordered parts (Figure S4, Supplementary Materials). The Addison criteria $\tau$ for the two complex parts are 0.26 and 0.05 for the disordered parts $\mathrm{A}$ and $\mathrm{B}$, respectively. These calculations indicate that the two complex parts have different coordination geometries: part $\mathbf{B}$ is closer to being a more perfect square pyramid than part $\mathbf{A}$. Regarding the scale factors for the two domains $\mathrm{A}$ and $\mathrm{B}$, both are close 0.5. Thus, if the Cl1A and $\mathrm{Cl} 2 \mathrm{~B}$ atoms, as well as $\mathrm{Cl1B}$ and $\mathrm{Cl} 2 \mathrm{~A}$, are assumed to belong to the same polyhedron, the $\tau$ values are calculated to be same $(\tau=0.26$ and 0.05$)$, which confirms our conclusion.

The different hydrogen bridge contacts controlling the molecular packing of complex 2 are listed in Table 3 and shown in Figure 3, while the molecular packing showing the different molecular units packed via $\mathrm{C}-\mathrm{H} \ldots \mathrm{Cl}$ interactions is shown in the lower part of Figure 4. Complex 2 also shows a 3D network connected via $\mathrm{Cl} \ldots \mathrm{H}$ interactions. Although the coordination modes of both complexes 1 and 2 look very similar, the hydrogen bridge networks turn out to be quite different. Small changes of the ligand molecule lead to significant differences in the packing.

Table 4. Bond distances and angles in 2.

\begin{tabular}{|c|c|c|c|}
\hline Atoms & Distance (̊̊) & Atoms & Distance (£) \\
\hline Fe1-N1 & $2.038(3)$ & $\mathrm{Fe} 2-\mathrm{Cl}$ B & $2.085(3)$ \\
\hline Fe1-N2 ${ }^{1}$ & $2.099(3)$ & $\mathrm{Fe} 2-\mathrm{Cl}^{2}{ }^{2}$ & $2.1667(10)$ \\
\hline Fe1-N2 & $2.099(3)$ & $\mathrm{Fe} 2-\mathrm{Cl} 3$ & $2.1668(10)$ \\
\hline Fe1-Cl1A & $2.250(3)$ & $\mathrm{Fe} 2-\mathrm{Cl} 4 \mathrm{~A}$ & $2.329(3)$ \\
\hline $\mathrm{Fe} 1-\mathrm{Cl} 2 \mathrm{~A}$ & $2.262(5)$ & & \\
\hline Fe1-Cl1B & $2.151(2)$ & & \\
\hline $\mathrm{Fe} 1-\mathrm{Cl} 2 \mathrm{~B}$ & $2.090(6)$ & & \\
\hline Atoms & Angle $\left(^{\circ}\right)$ & Atoms & Angle $\left(^{\circ}\right)$ \\
\hline N1-Fe1-N2 ${ }^{1}$ & $73.66(7)$ & Cl2B-Fe1-N2 & $101.82(8)$ \\
\hline N1-Fe1-N2 & $73.66(7)$ & N1-Fe1-Cl1B & 149.41(12) \\
\hline $\mathrm{N} 2{ }^{1}-\mathrm{Fe} 1-\mathrm{N} 2$ & $146.19(13)$ & Cl2B-Fe1-Cl1B & $90.49(17)$ \\
\hline N1-Fe1-Cl1A & $130.50(12)$ & N2 ${ }^{1}-\mathrm{Fe} 1-\mathrm{Cl} 1 \mathrm{~B}$ & 101.81(7) \\
\hline $\mathrm{N}^{1}{ }^{1}-\mathrm{Fe} 1-\mathrm{Cl} 1 \mathrm{~A}$ & $97.28(7)$ & N2-Fe1-Cl1B & $101.81(7)$ \\
\hline N2-Fe1-Cl1A & $97.28(7)$ & $\mathrm{Cl} 1 \mathrm{~A}-\mathrm{Fe} 1-\mathrm{Cl} 2 \mathrm{~A}$ & 122.17(15) \\
\hline N1-Fe1-Cl2A & 107.33(16) & $\mathrm{Cl} 4 \mathrm{~B}-\mathrm{Fe} 2-\mathrm{Cl} 3^{2}$ & $106.87(8)$ \\
\hline $\mathrm{N} 2{ }^{1}-\mathrm{Fe} 1-\mathrm{Cl} 2 \mathrm{~A}$ & $98.86(8)$ & $\mathrm{Cl} 4 \mathrm{~B}-\mathrm{Fe} 2-\mathrm{Cl} 3$ & 120.70(11) \\
\hline N2-Fe1-Cl2A & $98.86(8)$ & $\mathrm{Cl}^{2}-\mathrm{Fe} 2-\mathrm{Cl} 3$ & $109.97(6)$ \\
\hline N1-Fe1-Cl2B & 120.10(17) & $\mathrm{Cl}^{2}-\mathrm{Fe} 2-\mathrm{Cl} 4 \mathrm{~A}$ & $105.43(8)$ \\
\hline Cl2B-Fe1-N2 ${ }^{1}$ & $101.82(8)$ & $\mathrm{Cl} 3-\mathrm{Fe} 2-\mathrm{Cl} 4 \mathrm{~A}$ & $102.31(10)$ \\
\hline
\end{tabular}

\subsubsection{Crystal Structure Description of $\left[\mathrm{H}\left({ }^{\text {bisMorph }} \mathrm{PT}\right)\right]\left[\mathrm{FeCl}_{4}\right]^{\text {bisMorph }} \mathbf{P T} .2 \mathrm{H}_{2} \mathrm{O}(3)$}

Attempts to synthesize a coordination complex compound of the bisMorph PT ligand with $\mathrm{FeCl}_{3}$

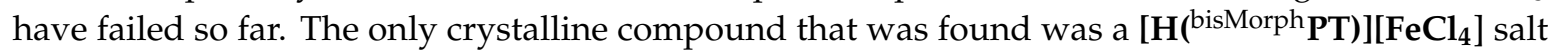
with one co-crystallized bisMorph PT ligand and two crystal water molecules in the asymmetric unit $(Z=2)$ of the triclinic unit cell with the symmetry P-1.

Compound 3 comprises four parts: the protonated organic ligand $\left[\mathbf{H}\left({ }^{\text {bisMorph }} \mathbf{P T}\right)\right]^{+}$as a cationic part, one electrically neutral bisMorph PT molecule, a negatively charged $\left[\mathrm{FeCl}_{4}\right]^{-}$ion, and two crystal water molecules in a void of the packing (Figure 5). The crystal quality of this compound was not very good. We found some disorder in the organic part of the crystal structure, and the protons of the crystal water molecules were not detectable. For these reasons, we only give the crystallographic data in this 
publication and do not further describe its molecular and supramolecular aspects in detail. Although our attempts to synthesize a complex containing the bisMorph PT ligand and $\mathrm{FeCl}_{3}$ were not successful, it does not necessarily mean that such a compound does not exist. In any case, it seemed to be useful to publish the data of compound $\mathbf{3}$ found in this context in order to create a reference for subsequent work. One possible reason for not obtaining a coordination complex of Fe(III) with the bidentate bisMorph PT ligand is its lower denticity compared to the tridentate ${ }^{\text {Pip } B P T}$ and ${ }^{M o r p h}$ BPT pincer chelates. Another possible reason is the steric effect resulting from the replacement of one pyrazole moiety by the morpholine one. The latter has no coordinating ability and a more bulky character that prevents the bisMorph $P$ T from coordinating to the Fe(III) ion.

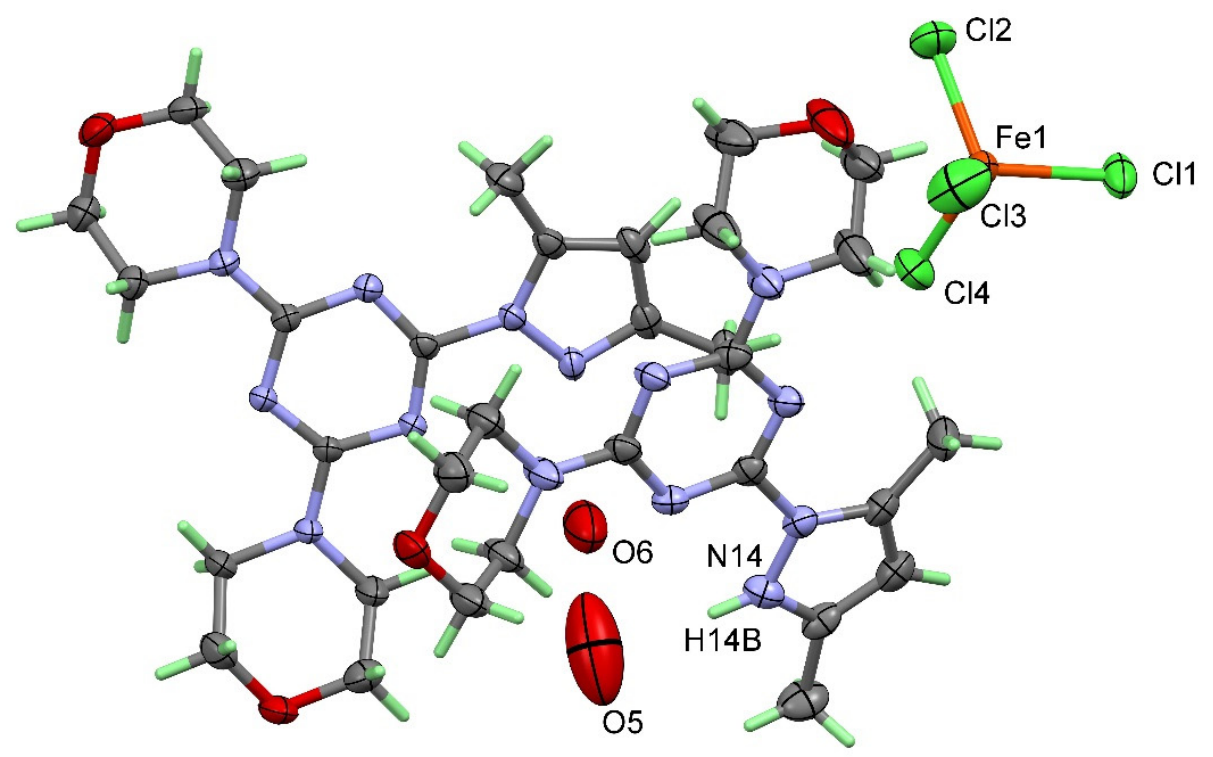

Figure 5. X-ray structure of compound 3. All atoms have been drawn at a 50\% probability level.

\subsection{Analysis of Molecular Packing}

Hirshfeld surfaces mapped over $\mathrm{d}_{\text {norm, }}$, shape index (SI), and curvedness for complexes $\mathbf{1}$ and $\mathbf{2}$ are shown in Figure S5 (Supplementary Materials). A summary of the most important contacts and their percentages are shown in Figure 6, while the decomposed $d_{\text {norm }}$ maps of the short and most significant contacts in the studied complexes are collected in Figure 7. The decomposed fingerprint plots indicate the same common contacts in both complexes, which are $\mathrm{H} \ldots \mathrm{H}$ and $\mathrm{Cl} \ldots \mathrm{H}$ interactions, the most abundant intermolecular interactions in the studied complexes. The percentages of these contacts are $40.1 \%$ and $37.4 \%$ in complex $\mathbf{1}$, respectively while they are $32.4 \%$ and $37.8 \%$ in complex 2 , respectively. The $\mathrm{Cl} \ldots \mathrm{H}$ hydrogen bonds appear as red regions in the Hirshfeld $\mathrm{d}_{\text {norm }}$ maps in both complexes and indicate shorter contact distances than the van der Waals $(\mathrm{vdW})$ radii sum of $\mathrm{H}$ and $\mathrm{Cl}$ atoms. The anion $\left(\mathrm{FeCl}_{4}{ }^{-}\right)-\pi$ stacking interactions are significant in both complexes. Complexes $\mathbf{1}$ and $\mathbf{2}$ show significantly short $\mathrm{C} \ldots \mathrm{Cl}$ and $\mathrm{N} \ldots \mathrm{Cl}$ contacts, with interaction distances also found to be shorter than the van der Waals radii sum of the two elements sharing this contact (Figure 7). The contact distances of the $\mathrm{N}$... Cl interactions are $3.213 \AA$ and $3.226 \AA$ for complexes $\mathbf{1}$ and 2, respectively, while the $\mathrm{C}$.. Cl contact distances are $3.257 \AA$ and $3.381 \AA$ for complexes $\mathbf{1}$ and 2, respectively. In complex $\mathbf{1}$, there is one short $\mathrm{Fe} 1 \ldots \mathrm{Cl} 3$ interaction $(3.708 \AA$ ) between the complex cation and one of the $\mathrm{Cl}$ atoms from the complex anion $\left(\mathrm{FeCl}_{4}^{-}\right)$. 


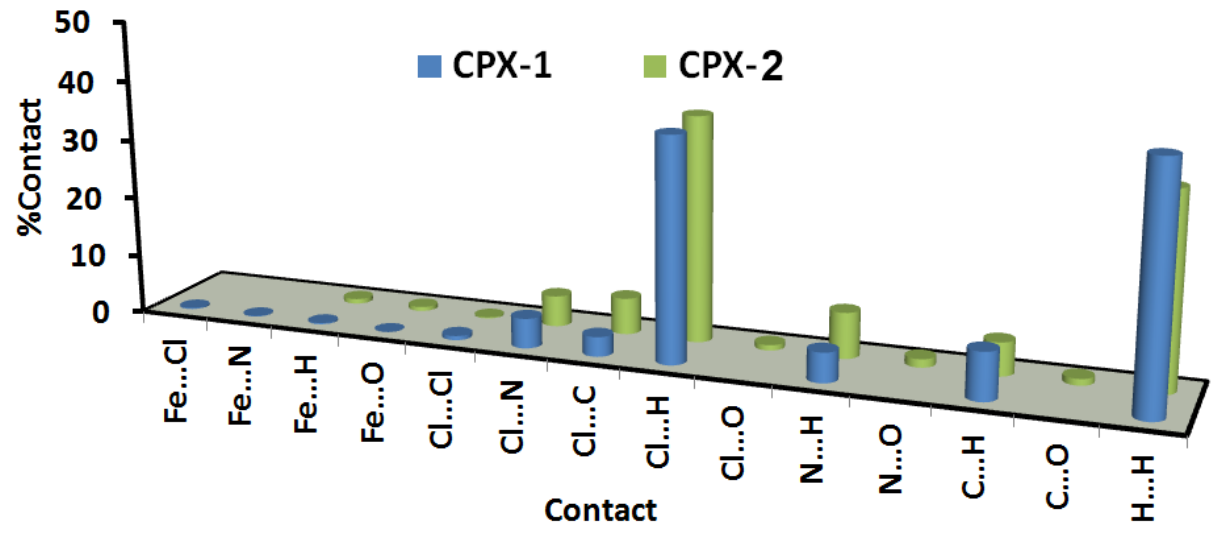

Figure 6. All intermolecular interactions in complexes (CPXs) 1 and 2.

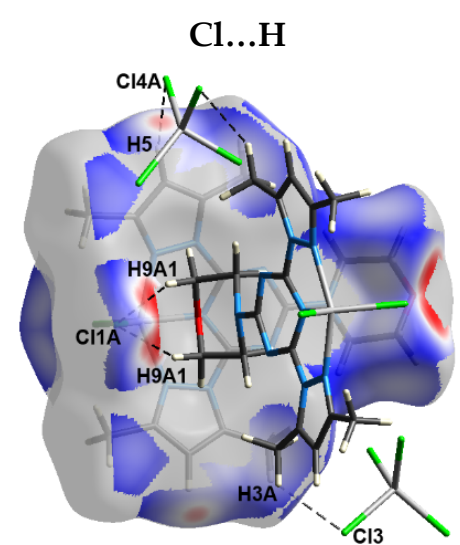

Cl...H
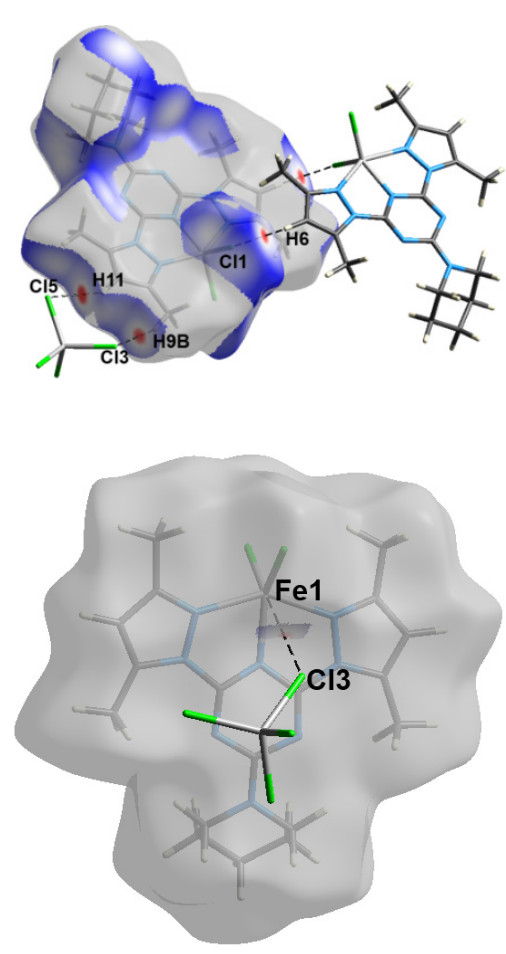

Cl...N

Cl...C

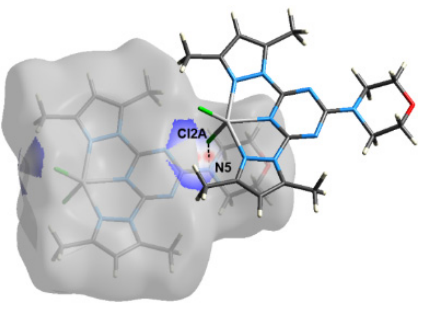

\section{CPX-2}

Cl...C

Cl...N
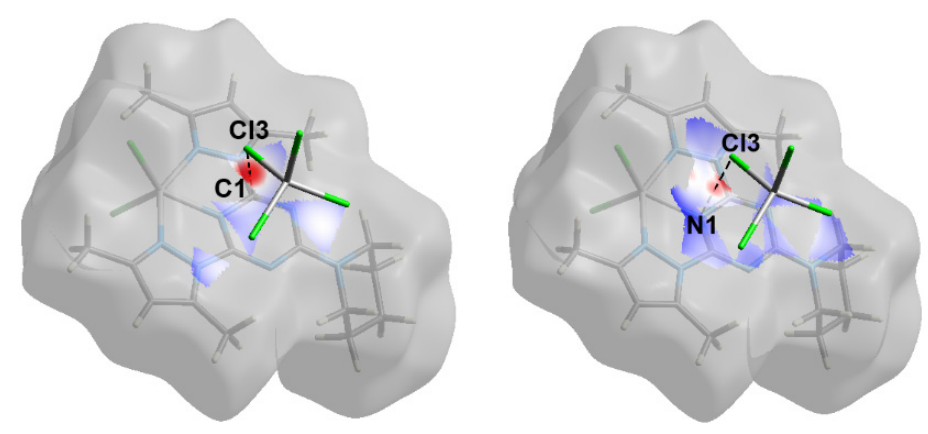

CPX-1

Figure 7. The decomposed $\mathrm{d}_{\text {norm }}$ maps and fingerprint plots of the most important contacts in $\mathbf{1}$ and 2. 


\subsection{Antimicrobial Activity of the Studied Compounds}

\subsubsection{Inhibition Zones}

In the current study, the antibacterial activity of the free ligands as well as compounds 1-3 were tested against Gram-positive bacteria, namely, Staphylococcus aureus (ATCC 29213) and Staphylococcus epidermidis (ATCC 12228); and Gram-negative bacteria, namely, Escherichia coli (ATCC 25922) and

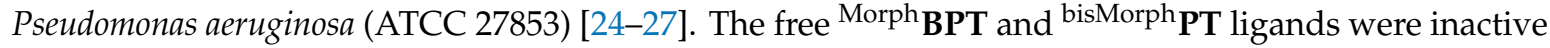
against the target microbes at the applicable concentration. On other hand, Pip BPT showed good activity against S. aureus, S. epidermidis, P. aeruginosa, and Candida albicans (ATCC 60193) and it was completely inactive against $E$. coli (Table 5). In contrast, Fe(III) compounds 1-3 showed more potent activities against the target pathogenic microbes than did the corresponding free ligands, as illustrated from the values of the inhibition zones $(\mathrm{mm})$ in Table 5 . The values are considered an indicator for the bioactivity of the tested compounds at a concentration of $200 \mu \mathrm{g} / \mathrm{mL}$. Compounds 1-3 appeared to have a more potent bioactivity against the target Gram-positive pathogenic bacteria than against the Gram-negative ones, and showed potent activity against the tested fungus (C. albicans).

Table 5. Anti-microbiological activities of the studied compounds against some tested microbes at 200 $\mu \mathrm{g}$ by the agar well diffusion method.

\begin{tabular}{|c|c|c|c|c|c|}
\hline \multirow{2}{*}{$\begin{array}{c}\text { Test } \\
\text { Compounds }\end{array}$} & \multicolumn{5}{|c|}{ Microbes } \\
\hline & $\begin{array}{c}\text { Staphylococcus } \\
\text { aureus }\end{array}$ & $\begin{array}{l}\text { Staphylococcus } \\
\text { epidermidis }\end{array}$ & $\begin{array}{c}\text { Escherichia } \\
\text { coli }\end{array}$ & $\begin{array}{l}\text { Pseudomonas } \\
\text { aeruginosa }\end{array}$ & $\begin{array}{l}\text { Candida } \\
\text { albicans }\end{array}$ \\
\hline Pip BPT & 11 & 17 & - & 13 & 12 \\
\hline Morph BPT & - & - & - & - & - \\
\hline bisMorph PT & - & - & - & - & - \\
\hline 1 & 25 & 23 & 19 & 22 & 18 \\
\hline 2 & 18 & 19 & 16 & 17 & 14 \\
\hline 3 & 17 & 16 & 14 & 15 & 12 \\
\hline Fluconazole & - & - & - & - & 14 \\
\hline Gentamycin & 28 & 22 & 21 & 19 & - \\
\hline
\end{tabular}

Complex 1 showed the most potency as an antibacterial and antifungal agent against all the target microbes, while 3 showed the lowest bioactivity. Additionally, complex 1 (18 mm) had better antifungal activity than the standard fluconazole $(14 \mathrm{~mm})$. Complex 1 had better antibacterial action against $S$. epidermidis $(23 \mathrm{~mm})$ and P. aeruginosa $(22 \mathrm{~mm})$ than the standard drug gentamycin $(22 \mathrm{~mm}$ and $19 \mathrm{~mm}$, respectively).

The antimicrobial activities of the studied compounds were also evaluated at different concentrations of $100 \mu \mathrm{g} / \mathrm{mL}, 200 \mu \mathrm{g} / \mathrm{mL}$, and $300 \mu \mathrm{g} / \mathrm{mL}$ per disc, as shown in Table 6. Compounds 1-3 at these concentrations showed moderate to strong activity against all tested microbes, even at the lowest concentration of $100 \mu \mathrm{g} / \mathrm{mL}$, where the best results were obtained for complex 1. On the other hand, as the concentration of the tested compound increased, the inhibition zone also increased. This result reveals that the presence of the piperidine/bis-pyrazolo combination with Fe(III) in one compound is the key for the bioactivity. These data agree with the literature, where the presence of piperidine enhanced the activity compared to the analogous morpholine derivatives [27].

\subsubsection{Minimum Inhibitory Concentration (MIC) and Minimum Bactericidal Concentration (MBC)}

The minimum inhibitory concentrations (MIC) of compounds 1-3 are given in Table 7. All tested compounds were active against S. aureus, S. epidermidis, E. coli, P. aeruginosa, and C. albicans. Again, complex 1 had the lowest MIC and MBC values, indicating its higher potency against all tested microbes as compared to 2 and 3 (Table 7). 
Table 6. Antimicrobial activities of Pip BPT and 1-3 at different concentrations.

\begin{tabular}{ccccc}
\hline \multirow{2}{*}{ Compounds } & Organism & \multicolumn{3}{c}{ Concentration } \\
\cline { 3 - 5 } & & $\mathbf{1 0 0}$ & $\mathbf{2 0 0}$ & $\mathbf{3 0 0}$ \\
\hline \multirow{3}{*}{$\mathbf{1}$} & E. coli & 16 & 19 & 21 \\
& P. aeruginosa & 20 & 22 & 23 \\
& S. aureus & 19 & 25 & 26 \\
& S. epidermidis & 18 & 23 & 25 \\
& C. albicans & 14 & 18 & 20 \\
\hline \multirow{3}{*}{ Pip $\mathbf{B P T}$} & E. coli & - & - & - \\
& P. aeruginosa & 13 & 15 & 18 \\
& S. aureus & 17 & 18 & 19 \\
& S. epidermidis & 11 & 13 & 15 \\
& C. albicans & 10 & 11 & 13 \\
\hline \multirow{2}{*}{2} & E. coli & 14 & 16 & 18 \\
& P. aeruginosa & 14 & 17 & 18 \\
& S. aureus & 14 & 18 & 19 \\
& S. epidermidis & 15 & 19 & 20 \\
& C. albicans & 12 & 14 & 16 \\
\hline \multirow{3}{*}{3} & E. coli & 12 & 15 & 17 \\
& P. aeruginosa & 12 & 15 & 17 \\
& S. aureus & 14 & 17 & 19 \\
& S. epidermidis & 13 & 16 & 17 \\
& C. albicans & 11 & 12 & 15 \\
\hline \multirow{2}{*}{3} & & & &
\end{tabular}

Table 7. Minimum inhibitory concentrations (MIC) $(\mu \mathrm{g} / \mathrm{mL})$ and minimum bactericidal concentrations $(\mathrm{MBC})(\mu \mathrm{g} / \mathrm{mL})$ of $\mathbf{1}-\mathbf{3}$ against the growth of target microbes.

\begin{tabular}{|c|c|c|c|c|c|c|}
\hline \multirow{2}{*}{ Microbes } & \multicolumn{2}{|c|}{$\left[\mathrm{Fe}\left({ }^{\mathrm{Pip}} \mathrm{BPT}\right) \mathrm{Cl}_{2}\right]\left[\mathrm{FeCl}_{4}\right](\mathbf{1})$} & \multicolumn{2}{|c|}{$\left[\mathrm{Fe}\left({ }^{\mathrm{Morph}} \mathrm{BPT}\right) \mathrm{Cl}_{2}\right]\left[\mathrm{FeCl}_{4}\right](2)$} & \multicolumn{2}{|c|}{$\left[\mathrm{H}\left({ }^{\text {bisMorph }} \mathrm{PT}\right)\right]\left[\mathrm{FeCl}_{4}\right] .{ }^{\text {bisMorph }} \mathrm{PT}(3)$} \\
\hline & MIC & MBC & MIC & MBC & MIC & MBC \\
\hline S. epidermidis & 8.3 & 16.6 & 9.7 & 19.4 & 18.8 & 37.5 \\
\hline S. aureus & 8.7 & 17.5 & 9.8 & 19.6 & 18.8 & 37.5 \\
\hline E. coli & 8.7 & 17.5 & 9.8 & 19.6 & 18.8 & 37.5 \\
\hline P. aeruginosa & 8.2 & 16.5 & 9.8 & 19.6 & 18.8 & 37.5 \\
\hline C. albicans & 18.8 & 100.0 & 37.5 & 150.0 & 37.5 & 150.0 \\
\hline
\end{tabular}

\section{Experimental}

\subsection{Materials and Physical Measurements}

Chemicals were purchased from Sigma-Aldrich Company. CHN analyses were performed using a Perkin Elmer 2400 Elemental Analyzer.

\subsection{Syntheses}

\subsubsection{Synthesis of $s$-Triazine-Based Ligands}

The ligands PipBPT, Morph BPT, and bisMorphPT were prepared following the method reported by our research group [21,22] (Supplementary Materials, Method S1 and Method S2, Figures S1-S3).

\subsubsection{Synthesis of Fe(III) Complexes}

All of the studied complexes were synthesized using a self-assembly technique, by mixing the aqueous solution of $\mathrm{FeCl}_{3}(1 \mathrm{mmol}, 162 \mathrm{mg})$ with the ethanolic solution of the functional ligand. The resulting clear solutions were left for slow evaporation until plate-like brown crystals of the target complexes were formed. The resulting crystals were collected by filtration and were found suitable for single-crystal X-ray diffraction measurements. 
Yield: $\mathrm{C}_{18} \mathrm{H}_{24} \mathrm{~N}_{8} \mathrm{Fe}_{2} \mathrm{Cl}_{6}(\mathbf{1}) 73 \%$ with respect to the ligand. Anal. Calc. C, $31.94 ; \mathrm{H}, 3.57 ; \mathrm{N}, 16.56 \%$. Found: $\mathrm{C}, 31.80 ; \mathrm{H}, 3.51 ; \mathrm{N}, 16.43 \%$.

Yield: $\mathrm{C}_{17} \mathrm{H}_{22} \mathrm{~N}_{8} \mathrm{OFe}_{2} \mathrm{Cl}_{6}$ (2) $76 \%$ with respect to the ligand. Anal. Calc. C, 30.08; H, 3.27; N, 16.51\%. Found: $\mathrm{C}, 29.90 ; \mathrm{H}, 3.21 ; \mathrm{N}, 16.38 \%$.

Yield: $\mathrm{C}_{32} \mathrm{H}_{51} \mathrm{~N}_{14} \mathrm{O}_{6} \mathrm{Fe} \mathrm{Cl}_{4}$ (3) $70 \%$ with respect to the ligand. Anal. Calc. C, 41.53; H, 5.55; N, 21.19\%. Found: $\mathrm{C}, 41.35 ; \mathrm{H}, 5.49 ; \mathrm{N}, 21.01 \%$.

\subsection{Crystal Structure Determination}

The crystal structures of complexes 1-3 were determined using a Bruker D8 Quest diffractometer employing SHELXTL and SADABS programs [28-30]. Hirshfeld calculations were performed using the default parameters of the Crystal Explorer 17.5 program [31-35].

\subsection{Antimicrobial Studies}

We determined the antimicrobial activities of the free ligands, as well as those of the corresponding $\mathrm{Fe}(\mathrm{III})$ complexes, against different microbes [22]. More details regarding the antimicrobial assay are found in Supplementary Materials (Methods S3-S6).

\section{Conclusions}

Three self-assembled Fe(III) complexes were synthesized by direct reaction of iron(III) chloride and the functional ligand in a water-alcohol medium. All complexes were obtained in good yield and their structures were confirmed by single-crystal X-ray diffraction. The supramolecular structures of complexes 1 and $\mathbf{2}$ were analyzed using Hirshfeld calculations with the aid of the CIF data. The Fe(III) complexes were bioactive against the target microbes and generally more active than the functional ligands. It was found that the combination of piperidine and bispyrazolo moieties with Fe(III) in one compound (1) had the best bioactivity in comparison with the corresponding complexes (2 and 3 ) comprised of morpholine group(s).

Supplementary Materials: The following are available online. Figure S1: ${ }^{1} \mathrm{H}-\mathrm{NMR}$ and ${ }^{13} \mathrm{C}-\mathrm{NMR}$ of ${ }^{\mathrm{Morph}} \mathrm{BPT}$, Figure S2: ${ }^{1} \mathrm{H}-\mathrm{NMR}$ and ${ }^{13} \mathrm{C}-\mathrm{NMR}$ of ${ }^{\text {Pip }} \mathbf{B P T}$, Figure S3: ${ }^{1} \mathrm{H}$ - and ${ }^{13} \mathrm{C}$-NMR for ${ }^{\text {bisMorph }} \mathrm{PT}$, Figure S4: Structure showing the disordered parts in 2. Figure S5: Hirshfeld surfaces mapped over $\mathrm{d}_{\text {norm }}$, shape index, and curvedness. In addition, the detailed synthesis of the ligands and biological experiments are given in the Supplementary data file. Methods S1-S6.

Author Contributions: The work was designed and supervised by S.M.S. X-ray structure analyses were performed by J.H.A. and S.M.S. Computational calculations as well as the synthesis of complexes 1-3 were carried out by S.M.S. and H.H.A.-R., and A.E.-F. carried out the preparation of the organic ligands, analysis, and the biological evaluation. All authors contributed in the first draft and the final version. All authors have read and agreed to the published version of the manuscript.

Funding: The Deanship of Scientific Research at King Saud University funded this research, grant number RGP-1441-234, Saudi Arabia.

Acknowledgments: The authors extend their thanks to the Deanship of Scientific Research at King Saud University for funding this work through research group number RGP-1441-234, Saudi Arabia.

Conflicts of Interest: The authors declare no conflict of interest.

\section{References}

1. Egorova, K.S.; Ananikov, V.P. Toxicity of Metal Compounds: Knowledge and Myths. Organometallics 2017, 36, 4071-4090. [CrossRef]

2. Egorova, K.S.; Ananikov, V.P. Which Metals are Green for Catalysis? Comparison of the Toxicities of Ni, $\mathrm{Cu}$, $\mathrm{Fe}, \mathrm{Pd}, \mathrm{Pt}$, Rh, and Au Salts. Angew. Chem. Int. Ed. 2016, 55, 12150-12162. [CrossRef] [PubMed]

3. Bauer, E.B. Iron Catalysis II. Top. Organomet. Chem. 2015, 50, 1-18.

4. Bolm, C.; Legros, J.; Le Paih, J.; Zani, L. Iron-Catalyzed Reactions in Organic Synthesis. Chem. Rev. 2004, 104, 6217-6254. [CrossRef] [PubMed]

5. Bauer, I.; Knölker, H.-J. Iron Catalysis in Organic Synthesis. Chem. Rev. 2015, 115, 3170-3387. [CrossRef] 
6. Wei, D.; Darcel, C. Iron Catalysis in Reduction and Hydrometalation Reactions. Chem. Rev. 2019, 119, 2550-2610. [CrossRef]

7. Ludwig, J.R.; Schindler, C.S. Catalyst: Sustainable Catalysis. Chemistry 2017, 2, 313-316. [CrossRef]

8. Soliman, S.M.; El-Faham, A. One pot synthesis of two Mn(II) perchlorate complexes with s-triazine NNN-pincer ligand; molecular structure, Hirshfeld analysis and DFT studies. J. Mol. Struct. 2018, 1164, 344-353. [CrossRef]

9. Soliman, S.M.; El-Faham, A. Synthesis, characterization, and structural studies of two heteroleptic Mn(II) complexes with tridentate N,N,N-pincer type ligand. J. Coord. Chem. 2018, 71, 2373-2388. [CrossRef]

10. Soliman, S.M.; El-Faham, A. Synthesis, molecular structure and DFT studies of two heteroleptic nickel(II) s-triazine pincer type complexes. J. Mol. Struct. 2019, 1185, 461-468. [CrossRef]

11. Soliman, S.M.; El-Faham, A. Synthesis, X-ray structure, and DFT studies of five and eight-coordinated Cd(II) complexes with s-triazine N-pincer chelate. J. Coord. Chem. 2019, 72, 1621-1636. [CrossRef]

12. Soliman, S.M.; Almarhoon, Z.; El-Faham, A. Synthesis, Molecular and Supramolecular Structures of New Cd(II) Pincer-Type Complexes with s-Triazine Core Ligand. Crystals 2019, 9, 226. [CrossRef]

13. Soliman, S.M.; Almarhoon, Z.; El-Faham, A. Bis-pyrazolyl-s-triazine Ni(II) pincer complexes as selective Gram positive antibacterial agents; synthesis, structural and antimicrobial studies. J. Mol. Struct. 2019, 1195, 315-322. [CrossRef]

14. Crisponi, G.; Remelli, M. Iron chelating agents for the treatment of iron overload. Coord. Chem. Rev. 2008, 252, 1225-1240. [CrossRef]

15. Brittenham, G.M. Hematology: Basic Principles and Practice; Hoffman, R., Benz, E., Shattil, S., Furie, B., Cohen, H., Eds.; Churchill Livingstone: New York, NY, USA, 1991; p. 327.

16. Al-Resayes, S.I.; Shakir, M.; Shahid, N.; Azam, M.; Khan, A.U. Synthesis, spectroscopic characterization and in vitro antimicrobial studies of Schiff base ligand, H2L derived from glyoxalic acid and 1,8-diaminonaphthalene and its $\mathrm{Co}(\mathrm{II}), \mathrm{Ni}(\mathrm{II}), \mathrm{Cu}(\mathrm{II})$ and $\mathrm{Zn}(\mathrm{II})$ complexes. Arab. J. Chem. 2016, 9, 335-343. [CrossRef]

17. Wenzel, M.; Patra, M.; Senges, C.H.R.; Ott, I.; Stepanek, J.J.; Pinto, A.; Prochnow, P.; Vuong, C.; Langklotz, S.; Metzler-Nolte, N.; et al. Analysis of the Mechanism of Action of Potent Antibacterial Hetero-tri-organometallic Compounds: A Structurally New Class of Antibiotics. ACS Chem. Biol. 2013, 8, 1442-1450. [CrossRef]

18. Patra, M.; Gasser, G.; Metzler-Nolte, N. Small organometallic compounds as antibacterial agents. Dalton Trans. 2012, 41, 6350-6358. [CrossRef]

19. Albada, H.B.; Prochnow, P.; Bobersky, S.; Bandow, J.E.; Metzler-Nolte, N. Highly active antibacterial ferrocenoylated or ruthenocenoylated Arg-Trp peptides can be discovered by an L-to-D substitution scan. Chem. Sci. 2014, 5, 4453-4459. [CrossRef]

20. Pansuriya, P.B.; Patel, M.N. Iron(III) complexes: Preparation, characterization, antibacterial activity and DNA-binding. J. Enzyme Inhib. Med. Chem. 2008, 23, 230-239. [CrossRef]

21. Farooq, M.; Sharma, A.; Almarhoon, Z.; Al-Dhfyan, A.; El-Faham, A.; Abu Taha, N.; Wadaan, M.A.M.; de laTorre, B.G.; Albericio, F. Design and synthesis of mono-and di-pyrazolyl-s-triazine derivatives, their anticancer profile in human cancer cell lines, and in vivo toxicity in zebrafish embryos. Bioorg. Chem. 2019, 87, 457-464. [CrossRef]

22. Sharma, A.; Ghabbour, H.; Khan, S.T.; de la Torre, B.G.; Albericio, F.; El-Faham, A. Novel Pyrazolyl-s-Triazine Derivatives, Molecular Structure and Antimicrobial Activity. J. Mol. Struct. 2017, 1145, 244-253. [CrossRef]

23. Addison, A.W.; Rao, T.N.; Reedijk, J.; Rijn, J.V.; Verschoor, G.C. Synthesis, structure, and spectroscopic properties of copper(II) compounds containing nitrogen-sulphur donor ligands; the crystal and molecular structure of aqua[1,7-bis(N-methylbenzimidazol-2'-yl)-2,6-dithiaheptane]copper(II) perchlorate. J. Chem. Soc. Dalton Trans. 1984, 1349-1356. [CrossRef]

24. De Souza, S.M.; Delle Monache, F.; Smânia, A. Antibacterial activity of coumarins. Z. Nat. C 2005, 60, 693-700. [CrossRef] [PubMed]

25. Arshad, M.; Bhat, A.R.; Hoi, K.K.; Choi, I.; Athar, F. Synthesis, characterization and antibacterial screening of some novel 1, 2, 4-triazine derivatives. Chin. Chem. Lett. 2017, 28, 1559-1565. [CrossRef]

26. Hassan, M.T.; Sareh, Z.J. Synthesis, Characterization and in Vitro Antimicrobial Screening of the Xanthate Derivatives and their Iron(II) Complexes. Iran. J. Chem. Chem. Eng. 2017, 36, 43-54.

27. Dhokale, N.T.; Karale, B.K.; Nagawadw, A.V. Synthesis, Characterization and Antibacterial Studies on Mn(II) and Fe(II) Complexes of N, O-Donor Salicyloyl Pyrazole Oxime Schiff Bases. Orient. J. Chem. 2017, 33, 165-172. [CrossRef] 
28. Sheldrick, G.M.; SADABS. Program for Empirical Absorption Correction of Area Detector Data; University of Göttingen: Göttingen, Germany, 1996.

29. Sheldrick, G.M. SHELXT-Integrated space-group and crystal-structure determination. Acta Crystallogr. Sect. A 2015, 71, 3-8. [CrossRef]

30. Spek, A.L. Structure validation in chemical crystallography. Acta Crystallogr. Sect. D 2009, 65, 148-155. [CrossRef]

31. Turner, M.J.; McKinnon, J.J.; Wolff, S.K.; Grimwood, D.J.; Spackman, P.R.; Jayatilaka, D.; Spackman, M.A. Crystal Explorer 17. 2017. University of Western Australia. Available online: http://hirshfeldsurface.net (accessed on 12 June 2017).

32. Spackman, M.A.; Jayatilaka, D. Hirshfeld surface analysis. CrystEngComm 2009, 11, 19-32. [CrossRef]

33. Spackman, M.A.; McKinnon, J.J. Fingerprinting intermolecular interactions in molecular crystals. CrystEngComm 2002, 4, 378-392. [CrossRef]

34. Bernstein, J.; Davis, R.E.; Shimoni, L.; Chang, N.-L. Patterns in hydrogen bonding: Functionality and graph set analysis in crystals. Angew. Chem. Int. Ed. Engl. 1995, 34, 1555-1573. [CrossRef]

35. McKinnon, J.J.; Jayatilaka, D.; Spackman, M.A. Towards quantitative analysis of intermolecular interactions with Hirshfeld surfaces. Chem. Commun. 2007, 3814-3816. [CrossRef] [PubMed]

Sample Availability: Samples of the compounds are available from the authors.

Publisher's Note: MDPI stays neutral with regard to jurisdictional claims in published maps and institutional affiliations.

(C) 2020 by the authors. Licensee MDPI, Basel, Switzerland. This article is an open access article distributed under the terms and conditions of the Creative Commons Attribution (CC BY) license (http://creativecommons.org/licenses/by/4.0/). 